\title{
Urinary tract infections among pregnant women in Mosul city
}

\author{
Dhukaa' A. Al-Jawadi \\ College of Nursing, University of Mosul.
}

(Ann. Coll. Med. Mosul 2012; 38 (2): 35-39).

Received: $2^{\text {nd }}$ Dec. 2010; Accepted: $4^{\text {th }}$ Dec. 2011.

\begin{abstract}
Objectives: To determine the prevalence of urinary tract infection (UTI) among pregnant women in Mosul city and to classify the infected women according to their trimesters of pregnancy. The sensitivity of isolated organisms to various antibiotics was also examined.

Patients and methods: Sample of 154 pregnant women attending Al-Batool Maternity Hospital in Mosul city from Feb-April 2007 was taken. Information on age, gestational age, gravidity, parity, level of education and residence were collected for each woman. Clean midstream urine samples were examined for UTI microscopically and culture, and sensitivity tests were done for the organisms isolated using a range of antibiotics.

Results: Prevalence rate of UTI among the studied subjects was $47.4 \%$. Eschirishia coli was the most frequently isolated organism (73.5\%) which was highly sensitive to nitrofurantoin, ciprofloxacin, gentamycin, ceftriaxone and amikacin. Amoxicillin, cotrimoxasole, tetracycline and ciprofloxacin are the effective antibiotics to half of isolated Gram positive bacteria. Of the variables examined, $79.5 \%$ of the infected participants were in the age group 20-35 years, $53.0 \%$ were in their third trimester, $41.0 \%$ had $1-4$ children, $30.1 \%$ were primigravidae, $63.0 \%$ attended the antenatal care unit on need, and $71.2 \%$ were urban at $6-12$ years schooling.

Conclusion: UTI is still a major health problem among pregnant women especially during their third trimester. Escherichia coli is the predominant pathogen causing UTI. All detected bacteria were sensitive to amikacin. Urinalyses with culture and sensitivity tests are mandatory for all pregnant women during the different trimesters. Health education with regular antenatal care share greatly in reducing the incidence of this infection.
\end{abstract}

Keywords: Prevalence, urinary tract infections, culture and sensitivity test.

الخلاصة الأهداف: لتحديد نسبة إنتشار إنتان المسالك البولية بين النساء الحوامل في مدينة الموصل وتصنيف هذا الإنتان حسب أثلوث الحمل

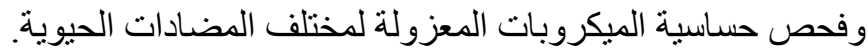

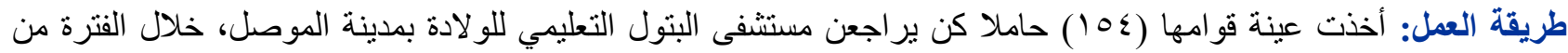

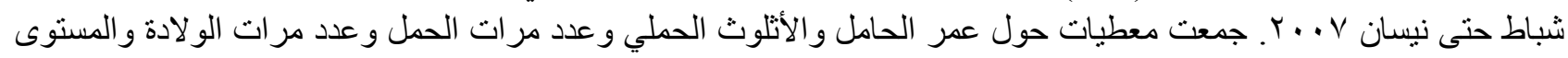

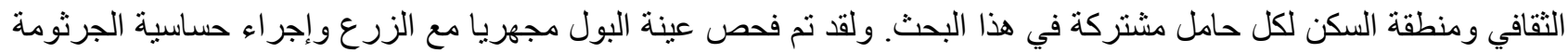

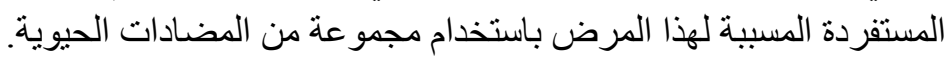

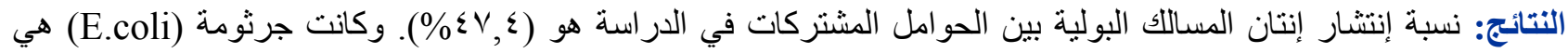

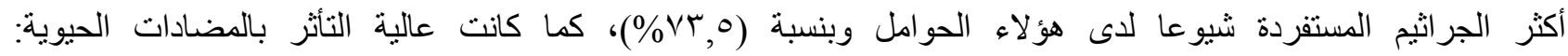

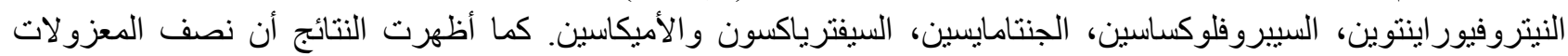

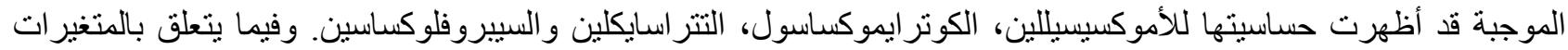

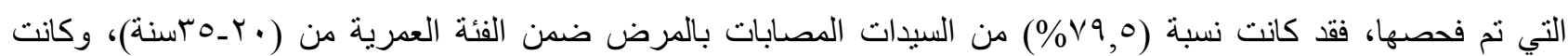

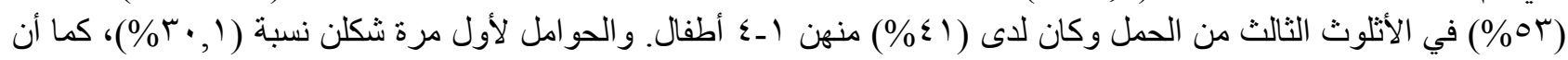




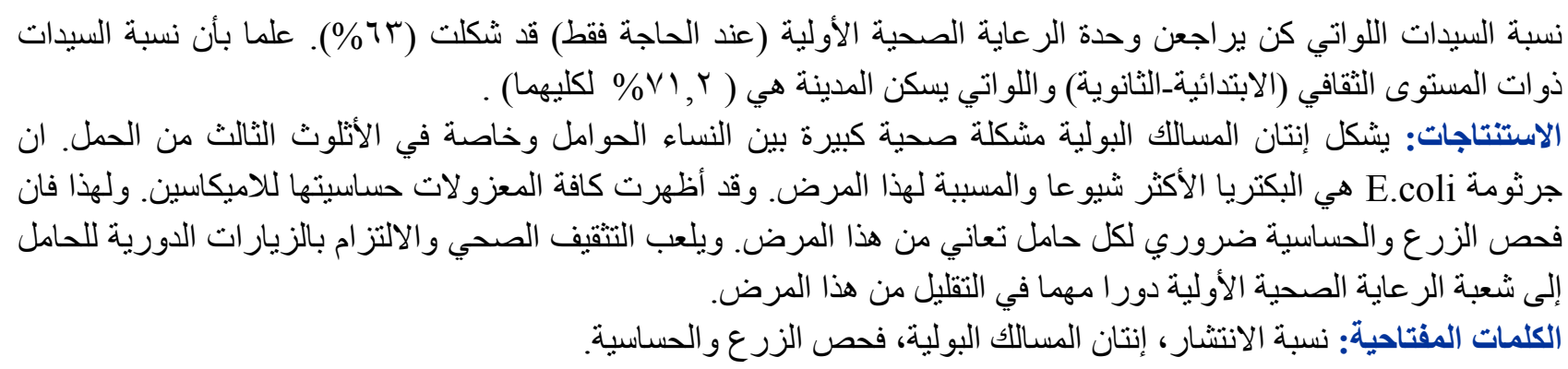

$U$ rinary tract infections (UTIs) are serious health problem affecting millions of people each year. ${ }^{(1)}$ Women are 30 times more likely to have UTI than men. Up to $60 \%$ of women will develop UTI at sometime in their lives. ${ }^{(2)}$ However, UTIs may be more serious during pregnancy because they are more likely to spread to the kidneys. ${ }^{(1)}$

During pregnancy, the tendency of UTI increases partly due to the pressure of the gravid uterus on the ureters causing stasis of urine flow and is also attributed to the humoral and immunological changes during normal pregnancy. ${ }^{(3,4)}$ Therefore, pregnant women should have a routine urine test in pregnancy. ${ }^{(5)}$ UTI occurs approximately in $5-10 \%$ of all pregnancies, ${ }^{(6,7)}$ and it can be seen in three different forms in pregnancy: asymptomatic bacteriuria, acute cystitis and/ or acute pyelonephritis. ${ }^{(1,5)}$ The incidence of asymptomatic bacteriuria has been reported between $2-13 \%$ in pregnancy all over the world and if not treated, it will increase the frequency of premature delivery and neonates with low birth weight and is likely to cause acute pyelonephritis at a rate of $15-30 \% .{ }^{(8-10)}$ Numerous studies during the past 30 years have reported association between UTI during pregnancy and adverse outcomes. ${ }^{(11)}$

The organisms that cause UTI during pregnancy are the same as those found in non-pregnant patients. Escherichia coli accounts for $80-90 \%$ of infections. Other Gram-negative rods such as Proteus mirabilis and Klebsiella pneumoniae are also common. Gram-positive organisms such as group-B streptococci and Staphylococcus saprophyticus are less common causes of UTI, in addition to Gardenella vaginalis, Ureaplasma urealyticum and Mycoplasma hominis. ${ }^{(6,2)}$ Urinalysis for detection of pyuria by microscope has a sensitivity of $80-90 \%$ and a specificity of $50 \%$ for predicting UTI. Urine culture is more expensive and requires $24-48$ hours for results. ${ }^{(12)}$ The American College of Obstetric and Gynecology stated that, a urine culture be obtained at the first prenatal visit and repeat urine culture should be obtained during the third trimester, because the urine of treated patients may not remain sterile for the entire pregnancy. ${ }^{(6)}$

The aims of this study are to determine the prevalence of UTI among pregnant women in Mosul city and to classify the infected women according to their trimesters of pregnancy. The sensitivity of isolated organisms to various antibiotics was also examined.

\section{PATIENTS AND METHODS}

Cross-sectional study design was adopted and AlBatool Maternity Hospital was the focal setting of this study. This hospital serves a population of different strata at right side of Tigris district in Mosul. For a period of three months (Feb-April 2007), a random sample of 154 pregnant women attending the antenatal care (ANC) unit at the study setting was taken. Information on maternal age, gestational age, parity, gravidity, child spacing, educational level, residence and employment was collected by face-to-face interview with the study subjects. Clean catch midstream urine was collected from the studied sample in sterile bottles. General urine examination was carried out for each woman. Accordingly, for the infected women, urine culture and sensitivity test was done. Plates of blood agar and MacConcky medium were aseptically inoculated with 2-3 drops of the urine precipitate and then incubated for 24-48 hours. The isolation of the pathogens were identified using Cowan and Steel method. ${ }^{(13)}$ The Kirby-Bauer disc diffusion method was adopted to perform the antibiotic sensitivity testing. ${ }^{(14)}$ The medium used for this purpose was Muller-Hinton agar. The antibiotic 
contents of the multidiscs were amoxycillin, rifampicin, cotrimoxazole, cefaloxine, tetracycline, nitrofurantoin, ciprofloxacin and gentamycin in different concentrations for Gram-positive bacteria. The antibiotic contents of multidiscs for Gramnegative bacteria were amoxycillin, rifampicin, nitrofurantoin, amikacin, nalidixic acid, cotrimoxazole, ceftriaxone, ciprofloxacin, tetracycline and gentamycin at the same concentrations as for the Gram-positive bacteria. Most of the essential materials used in this work were purchased personally from the local markets.

\section{RESULTS}

Of the 154 women tested, 73 women (47.4\%) were positive for UTI, while 81 women $(52.6 \%)$ were negative. The distribution of UTI among the infected women according to the sociodemographric and obstetric characterist-ics is shown in Table 1. The highest proportion (79.5\%) of UTI is seen among women aged 20-35 years. Housewives constituted $91.8 \%$ of the studied sample, $71.2 \%$ of them were urban at $6-12$ years schooling. Only $28.8 \%$ attend ANC unit regularly while, $63.0 \%$ attend it on need. Regarding the obstetric history, $69.9 \%$ of the infected women were multigravidae and those who have 1-4 children constituted $41.1 \%$ while, the grandmultiparous ( $>5$ children) women shared by nearly one quarter $(24.7 \%)$. Short child spacing $(<2$ years) was seen among $42.5 \%$ of the studied patients. According to the trimesters of pregnancy, the present study showed that, $30.0 \%$ of the infected women were in their first trimester, $44.0 \%$ in their second trimester and $53.0 \%$ in their third trimester with no significant statistical relationship $(p=0.15)$, (Table 2).

Of the total infected participants, bacteriuria was seen among $76.7 \%$, while pyuria was found among only $49.3 \%$, (Table 3 ). In relation to the culture and sensitivity test, positive growth of different bacteria was found among $46.6 \%$ of the infected patients, while the negative growth was seen among $53.4 \%$ of them. The highest proportion $(73.5 \%)$ of the positive growths was related to Escherichia coli, while Staphylococcus aureus, Proteus mirabilis and Pseudomonas aeruginosa shared by lesser proportions $(17.6 \%, 5.9 \%$ and $2.9 \%$ respectively), Table 4. All detected bacteria were sensitive to amikacin. Nitrofurantoin, gentamicin and nalidixic acid were effective agents against all isolates except Pseudomonas species. For Gram positive bacteria higher sensitivity percentages $(83.0 \%$ and $67.0 \%)$ were noted in case of gentamicin and nitrofurantoin. However, half of them were sensitive to amoxicillin, cotrimoxazole, tetracycline and ciprofloxacin (Table 5).

Table 1. Distribution of sociodemographic and obstetric characteristics among the study sample.

\begin{tabular}{|c|c|c|}
\hline \multirow[t]{2}{*}{ Characteristic } & \multicolumn{2}{|c|}{$\begin{array}{l}\text { Infected women } \\
\qquad(n=73)\end{array}$} \\
\hline & No. & $\%$ \\
\hline \multicolumn{3}{|l|}{ 1. Age (years) } \\
\hline$<20$ & 6 & 8.2 \\
\hline $20-35$ & 58 & 79.5 \\
\hline$>35$ & 9 & 12.3 \\
\hline \multicolumn{3}{|l|}{ 2. Employment } \\
\hline housewives & 67 & 91.8 \\
\hline employed & 6 & 8.2 \\
\hline \multicolumn{3}{|l|}{ 3. Residence } \\
\hline rural & 21 & 28.8 \\
\hline urban & 52 & 71.2 \\
\hline \multicolumn{3}{|l|}{ 4.Education (years of schooling) } \\
\hline no formal & 17 & 23.3 \\
\hline $6-12$ & 52 & 71.2 \\
\hline$>12$ & 4 & 5.5 \\
\hline \multicolumn{3}{|l|}{ 5. Antenatal care visit } \\
\hline regular & 21 & 28.8 \\
\hline on need & 46 & 63.0 \\
\hline not present & 6 & 8.2 \\
\hline \multicolumn{3}{|l|}{ 6. Gravidity } \\
\hline primigravida & 22 & 30.1 \\
\hline multigravida & 51 & 69.9 \\
\hline \multicolumn{3}{|l|}{ 7. Parity } \\
\hline Nullipara & 25 & 34.2 \\
\hline $1-4$ & 30 & 41.1 \\
\hline$\geq 5$ & 18 & 24.7 \\
\hline \multicolumn{3}{|l|}{ 8. Child spacing } \\
\hline$<2$ years & 31 & 42.5 \\
\hline$\geq 2$ years & 42 & 57.5 \\
\hline
\end{tabular}

Table 2. Distribution of UTI according to the three trimesters of pregnancy.

\begin{tabular}{|c|c|c|c|c|c|}
\hline \multirow[t]{2}{*}{$\begin{array}{l}\text { Trimester } \\
\text { of } \\
\text { pregnancy }\end{array}$} & \multicolumn{2}{|c|}{$\begin{array}{l}\text { Among total } \\
\text { women }\end{array}$} & \multicolumn{2}{|c|}{$\begin{array}{c}\text { Among } \\
\text { infected } \\
\text { women } \\
(n=73)\end{array}$} & \multirow[t]{2}{*}{$\begin{array}{c}\text { P- } \\
\text { value }\end{array}$} \\
\hline & No. & $\%$ & No. & $\%$ & \\
\hline First & 20 & 13.0 & 6 & 30.0 & \multirow{3}{*}{0.157} \\
\hline Second & 39 & 25.0 & 17 & 44.0 & \\
\hline Third & 95 & 62.0 & 50 & 53.0 & \\
\hline
\end{tabular}


Table 3. Distribution of the items of urinalysis among the infected subjects.

\begin{tabular}{|l|c|c|}
\hline \multicolumn{1}{|c|}{ Item } & No. & $\%$ \\
\hline Bacteria & 56 & 76.7 \\
\hline Pus & 36 & 49.3 \\
\hline Crystals & 18 & 24.7 \\
\hline Protein & 6 & 8.2 \\
\hline Red Blood Cells & 3 & 4.1 \\
\hline
\end{tabular}

Table 4. Results of urine culture among the studied women.

\begin{tabular}{|l|c|c|}
\hline \multicolumn{1}{|c|}{ Type of Bacteria } & \multicolumn{2}{|c|}{$\begin{array}{c}\text { Positive } \\
\text { No. }\end{array}$} \\
\hline Escherichia coli & 25 & 73.5 \\
\hline Staphylococcus aureus & 6 & 17.7 \\
\hline Proteus mirabilis & 2 & 5.9 \\
\hline $\begin{array}{l}\text { Pseudomonas } \\
\text { aeruginosa }\end{array}$ & 1 & 2.9 \\
\hline
\end{tabular}

Table 5. Percentage of the susceptibility of the isolated bacteria to antimicrobial drugs.

\begin{tabular}{|c|c|c|c|c|c|c|c|c|c|c|c|c|}
\hline Bacteria & $\begin{array}{l}\text { No. of } \\
\text { Isolates }\end{array}$ & \multicolumn{11}{|c|}{ Susceptibility of the isolated bacteria to antimicrobial drugs (\%) } \\
\hline Eschirichia coli & 25 & 12 & 12 & 12 & 0 & 8 & 48 & 48 & 44 & 24 & 12 & 40 \\
\hline Proteus mirabilis & 2 & 0 & 0 & 0 & 0 & 0 & 50 & 0 & 50 & 50 & 50 & 0 \\
\hline Peudomonas aeruginosa & 1 & 0 & 0 & 0 & 0 & 0 & 0 & 100 & 0 & 100 & 0 & 0 \\
\hline Staphylococcus aureus & 6 & 50 & 33 & 50 & 0 & 50 & 67 & 50 & 83 & 33 & 33 & 0 \\
\hline
\end{tabular}

Am.=Amoxicillin, Ri.=Rifampicin, Co.=Cotrimoxasole, Ce.= Cefaloxine, Te.= Tetracycline, Ni. $=$ Nitrofurantoin, Ci. $=$ Ciprofloxacin, Ge. $=$ Gentamicin, Ami. = Amikacin, Na. $=$ Nalidixic acid, Cef. $=$ Ceftriaxone.

\section{DISCUSSION}

UTIs are the widely spread infections seen in hospital settings, and the second commonest infections seen in the general population. ${ }^{(15)}$ In this study the prevalence of UTI among the studied pregnant women was $47.4 \%$. These results nearly corresponded with those of research workers in other countries, with minor differences, which could be due to variation in the environment, social habits of the community, and the standard of personal hygiene and education. ${ }^{(16)}$ In similar studies in our region, the prevalence was $38.0 \%$ in Iraq, ${ }^{(17)} 28.5 \%$ in Pakistan, ${ }^{(18)}$ and $10.6 \%$ in Turkey. ${ }^{(19)}$ The present study showed that, the highest proportion of UTIs was detected among women aged 20-35 years with high parity. This concurs with the study done by Krcmery et al, ${ }^{(20)}$ who stated that, the risk factors for UTI in women include: sexual intercourse, having first UTI at an early age, and having a maternal history of UTIs. UTI in the current study is frequently seen with increasing gestational age, which coincides with the findings of Sheik et al. ${ }^{(18)}$ The most common uropathogen isolated from urine of infected subjects of the present study was Escherichia coli which constituted $73.5 \%$. This is in agreement with the findings of Jonathan et al, ${ }^{(21)}$ who found that, Escherichia coli represents $80.0 \%$ of bacterial growth of infected women. Staphylococcal infection was seen among $17.6 \%$ of the infected women of the present study. Louise et al stated that, staphylococcus aureus is the second most common cause of UTI especially in young women. Proteus mirabilis and Pseudomonas aeruginosa are responsible for the remainders of uncomplicated UTIs. ${ }^{(22,23)}$ Based on the fact that the most offending pathogen is Escherichia coli, cephalosporine, amoxicillin or nitrofurantoin are reasonable choices. Trimethoprim is a folic acid antagonist therefore, it is generally avoided during organogenesis. ${ }^{(21,24,25)}$

\section{CONCLUSION}

It is concluded that, UTI is still a major health problem among pregnant women especially during their third trimester. Escherichia coli is the predominant pathogen causing UTI. All detected bacteria were sensitive to amikacin. Urinalysis with culture and sensitivity tests are mandatory for all pregnant women during the different trimesters. Health education with regular antenatal care share greatly in reducing this infection. 


\section{REFERENCES}

1. Hooton TM. Recurrent urinary tract infection in women. International Journal of antimicrobiol Agents 2001; 17(4): 259-68.

2. Olds SB, Ladewig W, Davidson MR. MaternalNewborn Nursing and Women's health Care. $7^{\text {th }}$ ed. United States of America: New Jersy; 2004. p.120-22.

3. WHO. Share with Women. Journal of Midwifery and Women's Health. Geneva: WHO 2005;50(6): 27.

4. Zeighmi H, Mota A, Rahmati M. Evaluation of Urinary Tract Infection in Pregnant Women. Journal of Biological Sciences 2008; 3(4): 441-3.

5. Tutuncu L, Ardic N. Urinary Tract Infection in Pregnancy. Prenatal Journal 2005; 13(4): 47.

6. Sengupta S. Cystone in urinary tract complaints during pregnancy. The Journal of Medicine and Surgery 1987; 11(27):87.

7. Todar K. Bacteriology. Science Magazine 2008; 304: 1421.

8. Alan H. Current Diagnosis and Treatment Obstetrics and Gynecology. $10^{\text {th }}$ ed. London: McGraw Hill Companies; 2007.p. 374-85.

9. Simon H. Urinary Tract Infection. 2003 [cited 2007 March 12]. Available form: URL:http://digitalcorpo ra.org/corp/nps/files/govdocs1/034/034243.

10. Benshushan A, Tsafrir A, Arbel R, Rahav G, Ariel I, Rojasky N. Listeria Infection during Pregnancy: A 10 years Experience. Israel Medical Association Journal 2002; 2(4):776-78.

11. Ramazan M, Bakhsh S, Salam A, Khan GM, Mustafa G. Risk factors in UTI. Comal Journal of Medical Sciences 2004; 2(1):15.

12. Gardwohl SE. Treatment UTI. 2005 [cited 2007 March 12]. Available form: URL:www.my/health/ world.com.

13. Cowan SF, Steel KJ. Manual for identification of medical bacteria. $3^{\text {rd }}$ ed. USA: Cambridge University Press; 1993.p. 23.
14. Bauer AW. Antibiotic susceptibility testing by standardized single disc method. American Journal of Clinical Pathology 1966; 45(3):493-6.

15. Valiquette L. Urinary tract infections in women. Canadian Journal of Urology 2001; 8(1):6-12.

16. Al-Haddad AM. Urinary Tract Infection among pregnant women in Al-Mukalla district, Yemen. Eastern Mediterranean Health Journal 2005;11(3): 505.

17. Al-Dujiaily AA. Urinary tract infection during pregnancy in Tikrit. Medical Journal of Tikrit 2000; 6(3):220-4.

18. Sheikh MA. Incidence of urinary tract infection during pregnancy. Eastern Mediterranean Health Journal 2000; 6(3): 265-71.

19. Kutlay S. Prevalence, detection and treatment of asymptomatic bacteriuria in a Turkish obstetric population. Journal of Reproductive Medicine 2003;48(8):627-30.

20. Krcmery S, Hromec J, Demesova D. Treatment of lower urinary tract infection in pregnancy. International Journal of Antimicrobial Agents 2001; 17(4):279-82.

21. Berek JS. NOVAK'S Gynecology: Urinary Tract Infection. $2^{\text {nd }}$ ed. Pheladelphia: Lippincott Williams \& Wilkins Publishers; 2002. p. 467.

22. Dembry LM, Vincent T. Infectious Diseases in Women: Urinary Tract Infections. USA: W.B Saunders Company; 2001. p. 354-64.

23. Mims C. Medical Microbiology. Updated $3^{\text {rd }}$ ed. Else Vier Limited, 2004. p. 241.

24. Collens S. Oxford Handbook of Obstetrics and Gynecology. $2^{\text {nd }}$ ed. Oxford: Oxford University Press. 2008. p.1.

25. Walker R, Edwards C. Clinical pharmacy and therapeutics: Drugs of choice for treatment of bacteriuria in pregnancy. $2^{\text {nd }}$ ed. London: Churchill Livingstone, 2004. p. 34. 